CAKRAWALA- Repositori IMWI | Volume 4, Nomor 1, April 2021

p-ISSN: 2620-8490; e-ISSN: 2620-8814

\title{
PENGARUH GAYA KEPEMIMPINAN DAN KESEJAHTERAAN TERHADAP KINERJA KARYAWAN (STUDI KASUS PADA HOTEL SELABINTANA)
}

\author{
Purwanto Rahardjo \\ Program Studi Admnistrasi Bisnis, Institut Manajemen Wiyata Indonesia \\ purwanto.rahardjo@imwi.ac.id \\ Ce Gunawan \\ Program Studi Admnistrasi Bisnis, Institut Manajemen Wiyata Indonesia \\ cegunawan28@gmail.com \\ Isriyani \\ Program Studi Admnistrasi Bisnis, Institut Manajemen Wiyata Indonesia \\ Isriyani33@gmail.com
}

\begin{abstract}
This study aims to determine: (1) the influence of leadership style on employee performance, (2) the influence of welfare on employee performance, and (3) the influence of leadership style and welfare on employee performance. The subjects of this research are employees who work at Selabintana Hotel. The number of respondents in this study were 102 employees. The method of collecting data through a survey using a questionnaire. The analysis technique used in this research is multiple linear regression analysis. The results showed that (1) leadership style had a positive and significant effect on employee performance, so Hal is accepted; (2) welfare has a positive and significant effect on employee performance, so Ha2 is accepted; (3) simultaneously, leadership style and welfare have a positive and significant effect on employee performance with detemination coefficient of 0,409 so that Ha3 is accepted.
\end{abstract}

Keywords: leadership style; welfare; employee performance.

\section{Pendahuluan}

Pada era globalisasi saat ini, perusahaan di Indonesia berkembang sangat maju. Dari perkembangan tersebut ada beberapa faktor yang menjadi penunjang berkembangnya perusahaan di Indonesia, diantaranya teknologi. Dengan berkembangnya teknologi maka akses berbisnis akan semakin mudah, sehingga dapat menumbuh-kembangkan kreativitas dan inovasi dalam dunia bisnis, baik yang bergerak di bidang jasa maupun dibidang non jasa. Hal inilah yang mengakibatkan persaingan antar pelaku bisnis di bidang tersebut semakin ketat. Sehingga untuk dapat mempertahankan bisnisnya maka pelaku bisnis harus mampu menyesuaikan dengan semua perkembangan yang ada, baik perkembangan teknologi maupun perkembangan ekonomi.

Perkembangan ekonomi suatu negara dapat dimulai dari perluasan perusahaan perorangan maupun badan usaha yang dimana perusahaan merupakan setiap bentuk usaha yang melakukan kegiatan secara tetap dan terus menerus dengan tujuan memperoleh keuntungan dan atau laba, baik yang diselenggarakan oleh orangperorangan maupun badan usaha yang berbentuk badan hukum atau bukan badan hukum, yang didirikan dan berkedudukan dalam wilayah Negara Republik Indonesia 
CAKRAWALA - Repositori IMWI | Volume 4, Nomor 1, April 2021 p-ISSN: 2620-8490; e-ISSN: 2620-8814

(Undang-Undang Nomor 8 Tahun 1997, n.d.).

Perusahaan baik negeri atau swasta, perorangan atau badan usaha memiliki suatu bagian yang sangat penting, yakni manajemen. Menurut George R. Terry (1997) bahwa manajemen adalah proses yang berbeda yang terdiri dari perencanaan (planning), pengorganisasian (organizing), pelaksanaan (actuating) dan pengawasan (controlling), yang dilakukan untuk menentukan dan mencapai tujuan yang dinyatakan dengan menggunakan manusia (sumber daya manusia) dan sumber daya lainnya.

Sumber Daya Manusia (SDM) merupakan sumber daya yang sangat penting dan strategis bahkan tidak dapat dilepaskan dari sebuah organisasi baik perusahaan maupun institusi dalam proses pencapaian tujuan perusahaan itu sendiri, yaitu sebagai pemikir, perencana dan sebagai pengendali aktivitas perusahaan. Sehingga perusahaan sudah faham betul bahwa sumber daya manusia merupakan salah satu faktor berkembangnya perusahaan dan penggerak jalannya perusahaan yang dharapan kinerjanya dapat membawa dampak baik bagi perusahaan. Kinerja karyawan yang bagus sangatlah diperlukan bagi perusahaan untuk mencapai tujuan perusahaan yang telah ditetapkan.

Menurut Sudaryono

menyebutkan bahwa Kinerja merupakan serangkaian kegiatan yang menggambarkan sejauh mana hasil yang sudah dicapai oleh seseorang dalam melaksanakan tugas dan tanggungjawabnya dalam bentuk akuntabilitas publik, baik berupa keberhasilan maupun kekurangan yang terjadi (Sudaryono, 2017).

Kinerja karyawan yang bagus akibat dari Pemberian kompensasi dan insentif tepat waktu merupakan salah satu faktor yang menunjang kesejahteraan karyawan. Undang- Undang No 13 tahun 2003 tentang ketenagakerjaan menyatakan bahwa kesejahteraan karyawan adalah suatu pemenuhan kebutuhan dan/atau keperluan yang bersifat jasmaniah dan rohaniah, baik di dalam maupun di luar hubungan kerja, yang secara langsung atau tidak langsung dapat mempertinggi produktivitas kerja dalam lingkungan kerja yang aman dan sehat (Undang- Undang No 13 Tahun 2003, n.d.).

Selain kesejahteraan karyawan yang menjadi faktor penunjang kinerja karyawan, gaya kepemimpian seorang pimpinan dalam perusahaan juga mempengaruhi kinerja karyawan dalam mencapai tujuan perusahaan. Menurut Emron Edison, dkk (2017) menyebutkan bahwa gaya kepemimpinan adalah cara seorang pemimpin bertindak dan/atau bagaimana ia mempengaruhi anggotanya untuk mencapai tujuan-tujuan tertentu (Komariyah, 2017).

Berikut data absensi karyawan Hotel Selabintana:

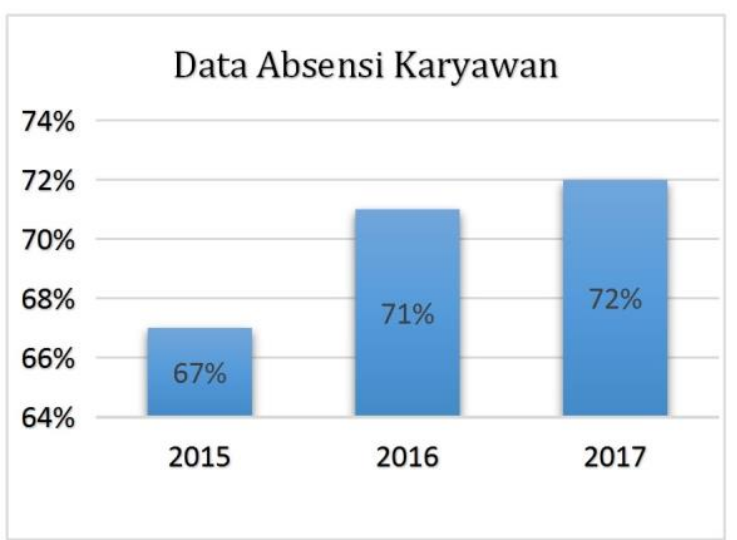

\section{Gambar 1}

\section{Grafik data absensi karyawan Hotel Selabintana}

\footnotetext{
Perusahaan perlu memberikan kesejahteraan yang cukup dan gaya kepemimpinan yang sesuai dengan karakter
} 
CAKRAWALA - Repositori IMWI | Volume 4, Nomor 1, April 2021

p-ISSN: 2620-8490; e-ISSN: 2620-8814

perusahaan dan karyawannya sehingga tercipta kinerja yang bagus dan memberikan dampak yang baik bagi perusahaan. Namun, jika dilihat dari fenomena yang terjadi di Hotel Selabintana, kesejahteraan yang diterima oleh karyawannya masih kurang serta gaya kepemimpinan yang kurang sesuai dengan karakter karyawannya sehingga menyebabkan kinerja karyawan jika dilihat dari absesnsi karyawan yang walaupun meningkat tapi tidak maksimal kurang maksimal.

Sehubungan dengan uraian diatas, maka dilakukan penelitian dengan judul "Pengaruh Gaya Kepemimpinan dan Kesejahteraan Terhadap Kinerja Karyawan Studi Kasus Pada Hotel Selabintana”.

\section{Tinjauan Pustaka}

\section{Gaya Kepemimpinan}

Menurut Hadari Nawawi (2003) menyatakan bahwa gaya kepemimpinan dapat diartikan sebagai perilaku atau cara yang dipilih dan dipergunakan pemimpin untuk mempengaruhi pikiran, perasaan, sikap dan perilaku anggota organisasi atau bawahannya (Sudaryono, 2017).

Menurut Gary Yukl (2015:3) menyatakan bahwa indikator gaya kepemimpinan sebagai berikut:

1) Kemampuan Mengambil Keputusan

Pengambilan keputusan adalah sesuatu yang sistematis terhadap hakikat alternatif yang dihadapi dan mengambil tindakan yang paling tepat.

2) Kemampuan Memotivasi Dalam rangka mencapai tujuan perusahaan, seorang pemimpin harus dapat memotivasi dan memberikan semangat kepada para bawahannya untuk bekerja lebih giat dan maksimal.

3) Kemampuan Komunikasi Kemampuan komunikasi sangatlah harus dimiliki oleh seorang pemimpin guna bisa menyampaikan pesan, ide, gagasan dan pemikiran kepada orang lain yang bertujuan agar orang lain dapat memahami apa yang di sampaikan sehingga tidak terjadi kesalahpahaman.

4) Kemampuan Mengendalikan

Bawahan

Seorang pemimpin harus mampU mengendalikan bawahannya dan mempengaruhi orang lain agar mau menjalankan perintah dan instruksi yang diberikan dengan menggunakan kekuatan pribadi atau kekuasannya secara efektif.

5) Tanggung Jawab

Seorang pemimpin harus bisa bertanggung jawab terhadap pekerjaannya, bawahan dan juga perusahaan.

6) Kemampuan Mengendalikan Emosional

Pemimpin juga harus mampu mengendalikan emosi, tidak terbawa suasana tetapi harus mampu memposisikan diri dengaN mengendalikan emosionalnya.

\section{Kesejahteraan}

Kesejahteraan adalah balas jasa lengkap (materi dan non materi) yang diberikan oleh perusahaan berdasarkan kebijaksanaan perusahaan (Malayu S.P Hasibuan, 206:183).

Menurut Hasibuan (2006: 188) indikator kesejahteraan antara lain:
1) Program
kesejahteraan
ekonomis 
CAKRAWALA - Repositori IMWI | Volume 4, Nomor 1, April 2021

p-ISSN: 2620-8490; e-ISSN: 2620-8814

Kesejahteraan ekonomis yang diterima karyawan bisa berupa uang pensiun setelah mencapai batas usia tertentu, pemberian tunjangan serta pemeliharaan kesehatan.

2) Program kesejahteraan fasilitas Kesejahteraan fasilitas disini maksudnya memfasilitasi karyawan dalam lingkungan bekerja agar merasakan kemudahan dan kenyamanan dalam bekerja seperti, adanya tempat ibadah agar karyawan tetap menjalankan salah satu kewajibannya pada Tuhan yang maha Esa, adanya kantin maupun koperasi, fasilitas transport, adanya poliklinik untuk menunjang kesehatan karyawan dan yang lainnya.

3) Program kesejahteraan pelayanan

Kesejahteraan pelayanan ini hendaknya mempermudah dan membantu karyawan dalam bekerja maupun dalam menghidupi keluarganya. Kesejahteraan pelayanan ini bisa berbentuk pinjaman kepada perusahaan yang di organisir oleh manajemen dan asuransi yang dimana biasanya perusahaan akan bekerja sama dengan sebuah perusahaan asuransi untuk menanggung asuransi karyawannya. Karena hampir setiap perusahaan memberikan kesejahteraan pelayanan terhadap semua karyawannya, terutama perusahaan besar namun untuk perusahaan kecil atau yang baru dibangun biasanya belum ada asurasi dengan alasan sedang diurus dan yang lainnya.

\section{Kinerja Karyawan}

Kinerja adalah hasil dari pekerjaan atau kegiatan individu atau kelompok dalam suatu organisasi yang dipengaruhi beberapa faktor dalam mencapai tujuan yang telah ditetapkan dalam periode waktu tertentu (Tika, 2006:26).

Menurut Robbin (2006) menyatakan indikator-indikator yang mempengaruhi kinerja sebagai berikut:

1) Pengetahuan tentang peraturan perusahaan merupakan salah satu kemampuan bahwa mereka memahami tugas dan tanggungjawab yang berkaitan dengan pekerjaannya.

2) Kemampuan manajerial merupakan kemampuan dalam bekerjasama dengan rekan kerja, selalu bersikap positif jika sedang bekerja dalam tim.

3) Kualitas pekerjaan dihasilkan dari mengukur orientasi karyawan terhadap kualitas pekerjaan yang dihasilkan serta kemampuan dan keterampilan yang diselesaikan dengan menggunakan standar yang telah ditetapkan.

4) Kuantitas pekerjaan merupakan jumlah produktivitas karyawan dalam kurun waktu tertentu (Yati Suhartini; Tri Septiningsih, 2014).

\section{Model Analis}

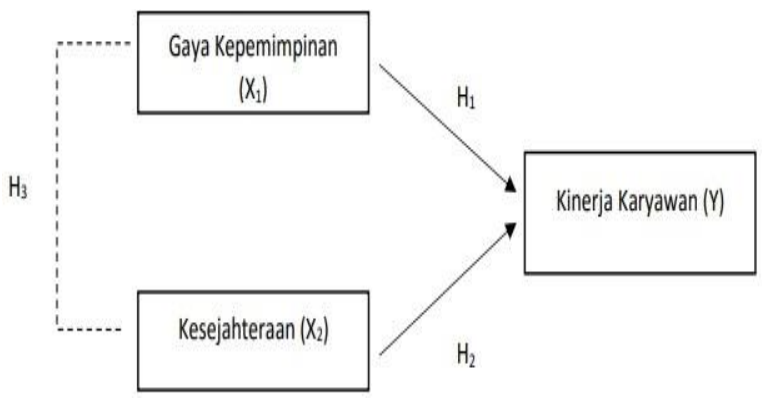

Hipotesis 
CAKRAWALA - Repositori IMWI | Volume 4, Nomor 1, April 2021

p-ISSN: 2620-8490; e-ISSN: 2620-8814

$\mathrm{H}_{0}$ 1: Gaya kepemimpinan tidak memiliki pengaruh positif terhadap

kinerja karyawan di Hotel Selabintana.

Ha1: Gaya kepemimpinan memiliki pengaruh positif terhadap kinerja karyawan di Hotel

Selabintana.

$\mathrm{H}_{0}$ 2: Kesejahteraan tidak memiliki pengaruh positif terhdap kinerja karyawan di Hotel Selabintana.

Ha2: Kesejahteraan memiliki pengaruh positif terhadap kinerja karyawan di Hotel

Selabintana.

$\mathrm{H}_{0} 3$ : Gaya kepemimpinan dan kesejahteraan secara bersama-sama

$$
n=\frac{N}{1+N e^{2}}
$$

tidak memiliki pengaruh terhadap kinerja karyawan di Hotel Selabintana.

Ha3: Gaya kepemimpinan dan kesejahteraan secara bersama - sama memiliki pengaruh terhadap kinerja karyawan di Hotel Selabintana.

\section{Metode Penelitian}

Dalam penelitian ini, penulis akan menjelaskan penelitian ini menggunakan deskriptif kuantitatif, yang dimana metode ini merupakan data yang diperoleh dari sample populasi penelitian kemudian dianalisis sesuai dengan metode statistik yang digunakan. Peneliti melakukan penelitian dengan objek penelitian gaya kepemimpinan, kesejahteraan dan kinerja karyawan dengan tujuan untuk mengetahui keterkaitan dari ketiga variabel tersebut. Pada penelitian ini digunakan unit analisis individu dalam suatu organisasi atau perusahaan. Hal ini bertujuan untuk mengetahui pengaruH gaya kepemimpinan dan kesejahteraan terhadap kinerja karyawan.

\section{Populasi dan Sampel}

Menurut sugiyono (2015:135) 52 bahwa populasi adalah wilayah generalisasi yang terdiri dari: objek atau subjek yang mempunyai kuantitas dan karakteristik tertentu yang ditetapkan oleh peneliti untuk dipelajari kemudian ditarik kesimpulannya (Sugiyono, 2015). Jumlah populasi dalam penelitian ini adalah seluruh karyawan yang bekerja di Hotel Selabintana yang berjumlah 137 orang karyawan. Untuk menghitung jumlah sampel yang digunakan Peneliti dalam penelitian ini menggunakan teknik Slovin. Berikut rumusnya:

\section{Keterangan:}

n: ukuran sampel atau jumlah responen

$\mathrm{N}$ : ukuran populasi

e: batas toleransi kesalahan sebesar 5\%

Sampel yang digunakan dalam penelitian ini sebagai bagian dari populasi yakni 102 orang karyaawan Hotel Selabintana guna mempermudah penelitian dalam pengolahan data.

\section{Teknik Pengambilan Sampel dan Penentuan Ukuran Sampel}

Pada peneitian ini peneliti menggunakan teknik simple Random sampling yang dimana teknik ini merupakan teknik yang dilakukan secara acak dan tanpa memandang strata yang ada dalam populasi tersebut. Menurut Suharsimi Arikunto teknik sampel acak ini karena didalamnya peneliti "mencampur" subjek - subjek 
CAKRAWALA - Repositori IMWI | Volume 4, Nomor 1, April 2021

p-ISSN: 2620-8490; e-ISSN: 2620-8814

di dalam populasi sehingga semua subjek dianggap sama. Dengan demikian, peneliti memberikan hak yang sama kepada setiap subjek untuk memperoleh kesempatan (chance) dipilih menjadi sampel. Karena hak setiap subjek sama, maka peneliti terlepas dari perasaan ingin mengisitimewakan satu atau beberapa subjek untuk dijadikan sampel (Arikunto, 2013).

\section{Teknik Pengumpulan Data}

1) Pengumpulan Data dengan Tes

Pengumpulan data dengan tes dilakukan dengan cara memberi sejumlah pertanyaan kepada subjek yang diteliti untuk dijawab.

2) Wawancara

Wawancara dapat dilakukan secara terstruktur maupun tidak terstruktur dan dapat dilakukan melalui tatap muka (face to face) maupun dengan menggunakan telepon atau internet.

3) Observasi atau Pengamatan Terstruktur

Observasi merupakan cara yang penting untuk mendapatkan informasi yang pasti tentang orang, karena apa yang dikatakan orang belum tentu sama dengan apa yang dikerjakan.

4) Teknik Pengumpulan Data dengan Kuesioner

Menurut Suharsimi

Arikunto menyebutkan bahwa kuesioner merupakan sejumlah petanyaan tertulis yang digunakan untuk memperoleh informasi dari responden, dalam arti laporan tentang pribadi atau hal yang diketahuinya.
Dari ke empat jenis pengumpulan data tersebut, peneliti menggunakan teknik pengumpulan data dengan kuesioner, yang dimana dilakukan pada sampel yang bekerja di Hotel Selabintana.

\section{Pengujian Kualitas Instrumen Pengukuran}

1) Uji Validitas

Uji validitas merupakan suatu bentuk pengukuran instrumen dalam penelitian yang dimana bertujuan untuk mengetahui apakah indikator dalam setiap variabel itu valid atau tidak. Dasar pengambilan keputusannya adalah:

a. Jika nilai $r$ hitung lebih besar dari $r$ tabel ( $r$ hitung > $r$ tabel), maka variabel tersebut adalah valid.

b. Jika nilai $r$ hitung lebih kecil dari $r$ tabel ( $\mathrm{r}$ hitung $<\mathrm{r}$ tabel), maka variabel tersebut adalah tidak valid.

Koefisien $r$ tabel didapat dari nilai tabel product moment berdasarkan $\alpha=5 \%$. Dari setiap variabel dengan 102 responden dan tingkat signifikan 5\% dinyatakan valid. Pada penelitian ini dengan $r$ tabel sebesar 0,195. memiliki nilai $r$ hitung lebih besar dari $\mathrm{r}$ tabel dan dinyatakan item - itemnya adalah valid. Dari tabel diatas dapat disimpulkan bahwa seluruh item pernyataan tersebut dinyatakan valid.

2) Uji Reliabilitas

Suharsimi Arikunto, menyatakan bahwa suatu instrumen cukup dapat dipercaya untuk digunakan sebagai alat pengumpul data karena instrumen tersebut sudah 
CAKRAWALA - Repositori IMWI | Volume 4, Nomor 1, April 2021

p-ISSN: 2620-8490; e-ISSN: 2620-8814

baik. Instrumen yang sudah dapat dipercaya, yang reliabel akan menghasilkan data yang dapat dipercaya juga. Disini yang dapat dipercaya bukan instrumennya, melainkan datanya. Reliabel artinya, dapat dipercaya, jadi dapat diandalkan. Rumus yang digunakan untuk menguji reliabilitas adalah rumus Alpha Cronbach (Arikunto, 2013).

\section{Uji Asumsi Klasik}

1) Uji Normalitas

Menurut (Gzohali, 2013) uji normalitas bertujuan untuk dapat mengetahui bahwa data yang ada terdistribusi normal dan independen. Pada uji normalitas ini, pengujian dilakukan pada variabel Gaya Kepemimpinan (X1), Kesejahteraan (X2) dan Kinerja Karyawan (Y). Untuk dapat melihat apakah data berdistribusi normal atau tidaknya penelitian ini menggunakan Kolmogrov Smirnov Goodness of Fit Test. Selain itu, data ini juga dibandingkan dengan Normality Probability Plot. Berikut kriteria dalam uji normalitas ini:

a) Angka sig. Uji Kolmogrov Smirnov > 0,05 maka berdistribusi normal.

b) Angka sig. Uji Kolmogrov Smirnov < 0,05 maka berdistribusi tidak normal

\section{2) Uji Multikolinieritas}

Uji Multikolinearitas merupakan keadaan dimana ada hubungan linier secara sempurna atau mendekati sempurna antara variabel independen dalam model regresi. Variabel yang menyebabkan multikolineritas dapat dilihat dari nilai toleransi yang lebih kecil 0,10 atau VIF yang lebih besar dari 10. Kriteria dalam uji multikolinieritas ini adalah:

a) Jika nilai VIF di sekitar angka 1 atau memiliki toleransi mendekati 1, maka dikatakan tidak terdapat masalah multikolinearitas.

b) Jika koefisien antar variabel bebas kurang dari 0.5, maka tidak terdapat masalah multikolinearitas.

\section{3) Uji Heteroskedastisitas}

Menurut (Gzohali, 2013) Uji Heteroskedastisitas adalah varian residual yang tidak sama ada semua pengamatan di dalam model regresi dimana regresi yang baik seharusnya tidak terjadi heteroskedasitas. Pengambilan keputusan yaitu dengan cara:

a) Jika ada pola tertentu, seperti titik - titik yang ada membentuk suatu pola tertentu yang teratur (bergelombang melebar kemudian menyempit), maka terjadi heteroskedastisitas.

b) Jika tidak ada pola yang jelas, seperti titik - titik yang menyebar di atas dan di bawah angka 0 pada sumbu $\mathrm{Y}$, maka tidak terjadi heteroskedastisitas dalam model regresi

\section{Pengujian Hipotesis}

1) Regresi Linear Berganda

Menurut (Gzohali, 2013) menyatakan bahwa analisis linier berganda digunakan oleh peneliti dimaksudkan untuk meramal bagaimana keadaan (naik turun) variabel devenden (kriterium), bila dua atau lebih variabel independen sebagai faktor prediktor di naik 
CAKRAWALA - Repositori IMWI | Volume 4, Nomor 1, April 2021

p-ISSN: 2620-8490; e-ISSN: 2620-8814

turunkannya. Menurut (Sugiyono, 2015) persamaan regresi linier berganda yang ditetapkan adalah sebagai berikut:

$\mathbf{Y}=\underline{\alpha}+B 1 \times 1+\beta 2 \times 2$

Keterangan:

Y :Variabel dependen Kinerja

Karyawan

$\underline{\alpha} \quad$ : Koefisien konstanta

B1.ß2: Koefisien regresi

$\mathrm{x} 1$ : Variabel terikat

Gaya Kepemimpinan

x2 :Variabel terikat 2 Kesejahteraan

2) $\mathrm{Uji} \mathrm{t}$

Uji statistik $t$ disebut juga sebagai uji signifikan individual yaitu menunjukkan seberapa jauh pengaruh variable independent terhadap variabel dependen secara parsial. Dalam Uji statistik t ini penulis menggunakan uji dua pihak (Two Tail Test). Uji dua pihak merupakan pengujian hipotesis karena adanya dua daerah penolakan. Uji dua pihak ini digunakan bila hipotesis Nol (Ho) berbunyi "sama dengan" dan hipotesis alternatifnya (Ha) berbunyi "tidak sama dengan" $(\mathrm{Ho}=; \mathrm{Ha} \neq$ ).

3) Uji F

Uji F digunakan untuk melihat apakah variabel independen secara bersama-sama (serentak) mempunyai pengaruh terhadap variabel dependen, bentuk pengujiannya sebagai berikut:

a) Ho3: $\mathrm{B} 1, \beta 2=0$, artinya tidak terdapat pengaruh Gaya
Kepemimpinan dan kesejahteraan terhadap kinerja karyawan.

b) Ha3: $\mathrm{B} 1, \beta 2 \neq 0$, artinya terdapat pengaruh Gaya Kepemimpinan dan kesejahteraan terhadap kinerja karyawan. Pengujian dengan tingkat signifikan pada tabel ANOVA $<\underline{\alpha}=0,05$ maka Ho ditolak (berpengaruh), sementara sebaliknya apabila tingkat signifikan tabel ANOVA $>\underline{\alpha}=0,05$ maka Ho diterima (tidak berpengaruh).

\section{HASIL PENELITIAN DAN \\ PEMBAHASAN}

\section{Uji Asumsi Klasik}

a. Uji Nomalitas

Berdasarkan hasil uji normalitas menunjukan bahwa hasil dari one sample KolmogorovSmirnov Asymp. Sig. (2-tailed) adalah 0,178 yang artinya penelitian ini berdistribusi normal karena nilai signifikasinya lebih besar dari 0,05 yaitu $(0,178>0,05)$.

b. Uji Multikolinieritas

Berdasarkan hasil uji multikolinieitas menunjukan bahwa variabel Gaya Kepemimpinan (X1) dan variabel Kesejahteraan (X2) memiliki nilai tolerance 0,842 yang dimana nilai ini lebih besar dari 0,10 yaitu $(0,842>0,10)$ dan nilai VIF nya sebesar 1,188 dimana nilai VIF nya lebih kecil dari 10 yaitu $(1,188<$ 10) sehingga dapat disimpulkan bahwa hasil uji multikolinieritas dari variabel X1 dan X2 dinyatakan tidak terjadi multikolinieritas sehingga 
CAKRAWALA - Repositori IMWI | Volume 4, Nomor 1, April 2021

p-ISSN: 2620-8490; e-ISSN: 2620-8814

hasil pengujiannya dinyatakan reliabel dan terpercaya.

c. Uji Heteroskedastisitas

Berdasarkan hasil uji heteroskedastisitas menunjukan bahwa tidak adanya pola yang jelas dan semua titik-titiknya menyebar diatas dan dibawah angka 0 pada sumbu Y, sehingga dapat disimpulkan bahwa pengaruh variabel X1, X2 dan variabel Y tidak terjadi heteroskedastisitas dalam model regresi, artinya tidak adanya penyimpangan dari asumsi klasik pada data yang dilakukan dalam pengujian ini.

\section{Pengujian Hipotesis}

1. Analisis Regresi Linear Berganda Hasil analisa regresi linear berganda menunjukan bahwa hasil uji regresi linear berganda memperoleh model regresi sebagai berikut: $\mathrm{Y}=8,264+0,478 * \mathrm{X} 1+$ $0,022 * \mathrm{X} 2$ dari interpretasi model regresi tersebut sebagai berikut:

a) $a=8,264$

Hasil ini merupakan total skor variabel Y sebesar 8,264 yang menunjukan bahwa tanpa adanya pengaruh dari variabel bebas terhadap variabel $\mathrm{Y}$ (Kinerja Karyawan).

b) b1 $=0,478 \quad$ Apabila ada peningkatan pada variabel X1 maka variabel $\mathrm{Y}$ pun akan meningkat dan hasil ini merupakan peningkatan pada total skor variabel $\mathrm{Y}$ jika terdapat kenaikan satu skala tanggapan pada variabel X1.3. b2 $=0,022$

Hasil ini menunjukan bahwa apabila ada kenaikan satu skala tanggapan terhadap variabel X2 maka akan terjadi peningkatan pula pada total skor variabel $\mathrm{Y}$ sebesar 0,022 . Sehingga apabila ada kenaikan pada variabel X2 maka variabel Y pun akan meningkat.

2. Uji t (Parsial)

Berdasarkan pada tabel hasil uji $\mathrm{t}$ menunjukan bahwa variabel Gaya kepemimpinan memperoleh nilai t hitung sebesar 7,603 dengan signifikan 0,000. Untuk mengetahui t tabel, distribusi t dapat dicari dengan $a=5 \%: 2=2,5 \%$ (uji 2 sisi) dengan derajat kebebasan (df) $\mathrm{n}-\mathrm{k}$ atau 102 $-3=99$ (n adalah jumlah responden dan $\mathrm{k}$ adalah jumlah variabel), dengan pengujian 2 sisi (signifikan 0,025), diperoleh hasil t tabel yaitu 1,985. Karena nilai $\mathrm{t}$ hitung lebih besar dari t tabel yaitu 7,603 > 1,985 dan nilai signifikan lebih kecil dari 0,05 yaitu $0,000<0,05$. Maka H01 ditolak dan Ha1 diterima. Sehingga dapat disimpulkan bahwa variabel Gaya Kepemimpinan (X1) memiliki pengaruh yang signifikan terhadap variabel Kinerja Karyawan (Y).

Hasil uji $t$ hitung variable kesejahteraan memperoleh nilai $\mathrm{t}$ hitung sebesar 5,415 dengan signifikan 0,000. Karena nilai $\mathrm{t}$ hitung lebih besar dari t tabel yaitu $5,415>1,985$ dan nilai signifikan lebih kecil dari 0,05 yaitu $0,000<$ 0,05 . Maka $\mathrm{H} 02$ ditolak dan $\mathrm{Ha} 2$ diterima. Sehingga dapat disimpulkan bahwa variabel Kesejahteraan (X2) memiliki pengaruh yang signifikan terhadap variabel Kinerja Karyawan (Y).

3. Uji F (Simultan) 
CAKRAWALA - Repositori IMWI | Volume 4, Nomor 1, April 2021

p-ISSN: 2620-8490; e-ISSN: 2620-8814

Berdasarkan tabel ANOVA menunjukan bahwa nilai Fhitung sebesar 35,940 dengan nilai signifikan 0,000. Nilai Ftabel dapat ditentukan dengan menggunakan tingkat kepercayaan 0,05 atau 5\% dengan rumusan df1=k-1 yaitu df1=3-1=2 dan df2=n $-\mathrm{k}$ yaitu $102-$ $3=99$. Maka dapat diperoleh nilai Ftabel sebesar 3,09. Karena Fhitung lebih besar dari Ftabel (35,940 > $3,09)$ dan nilai signifikan lebih kecil dari $0,05(0,000<0,05)$ maka H03 ditolak dan Ha3 diterima. Maka dapat disimpulkan bahwa variabel Gaya Kepemimpinan (X1), Kesejahteraan (X2) secara simultan berpengaruh terhadap variabel Kinerja karyawan (Y).

4. Analisis Koefisiensi

Determinasi (R2) Berdasarkan hasil Analisis Koefisiensi Determinasi (R2) menunjukan bahwa hasil uji koefisiensi determinasi (Adjusted $R$ Square) sebesar 0,409. Hal ini menjelaskan bahwa kontribusi dari bebas yaitu Gaya Kepemimpinan (X1) dan Kesejahteraan (X2) adalah sebesar $40,9 \%$ sedangkan sisanya $(100 \%$ $40,9 \%=50,1 \%$ pengaruh dari variabel lain yang tidak diteliti pada penelitian ini.

\section{Kesimpulan}

Penelitian ini dilakukan untuk mengetahui pengaruh gaya kepemimpinan dan kesejahteraan terhadap kinerja karyawan di Hotel Selabintana. Berdasarkan hasil penelitian yang berjudul Pengaruh Gaya Kepemimpinan dan Kesejahteraan terhadap Kinerja Karyawan di Hotel Selabintana dapat diambil simpulan sebagai berikut:
1. Gaya kepemimpinan berpengaruh secara positif dan signifikan terhadap kinerja karyawan Hotel Selabintana. Hal ini dapat dilihat dari hasil pengolahan data dan nilai t hitung sebesar 7,603 lebih besar dari t tabel yaitu 1,985 dengan signifikan 0,000 lebih kecil dari 0,005. Maka H01 ditolak dan Hal diterima. Sehingga dapat disimpulkan bahwa variabel Gaya Kepemimpinan (X1) memiliki pengaruh yang signifikan terhadap variabel Kinerja Karyawan (Y).

2. Gaya kepemimpinan berpengaruh secara positif dan signifikan terhadap kinerja karyawan Hotel Selabintana. Hal ini dapat dilihat dari hasil pengolahan data dan nilai t hitung sebesar 7,603 lebih besar dari t tabel yaitu 1,985 dengan signifikan 0,000 lebih kecil dari 0,005. Maka H01 ditolak dan Hal diterima. Sehingga dapat disimpulkan bahwa variabel Gaya Kepemimpinan (X1) memiliki pengaruh yang signifikan terhadap variabel Kinerja Karyawan (Y).

3. Variabel Gaya kepemimpinan (X1) Kesejahteraan (X2) secara simultan berpengaruh positif dan signifikan terhadap variabel kinerja karyawan (Y) di Hotel Selabintana. Dengan f hitung 35,940 lebih besar dari f tabel 3,09 dan nilai signifikan 0,000 lebih kecil dari 0,05 maka H03 ditolak dan Ha3 diterima. Hal ini dapat dilihat dari berdasarkan tabel diatas menunjukan bahwa hasil uji koefisiensi determinasi (Adjusted $R$ Square) sebesar 0,409. Hal ini menjelaskan bahwa kontribusi dari bebas yaitu Gaya Kepemimpinan (X1) dan Kesejahteraan (X2) adalah sebesar 40,9\% sedangkan sisanya $50,1 \%$ pengaruh dari variabel lain yang tidak diteliti pada penelitian ini. 
CAKRAWALA - Repositori IMWI | Volume 4, Nomor 1, April 2021

p-ISSN: 2620-8490; e-ISSN: 2620-8814

Saran

\section{Saran Teoritis}

a. Pengaruh dari variabel gaya kepemimpinan dan kesejahteraan berpengaruh positif dan signifikan terhadap kierja karyawan, sehingga diharapakan penelitian ini dapat menjadi bahan sebagai rekomendasi untuk yang akan datang.

b. Hasil penelitian ini juga diharapkan dpat dijadian bahan kajian, evaluasi dan diskusi disuatu perusahaa yang mengalami masalah ya sama.

\section{Saran Praktis}

a. Saran Untuk Perusahaan

Hasil penelitian variabel gaya kepemimpinandan kesejahteraan berpengaruh positif dan signifikan terhadap kinerja karyawan yang bekerja di Hotel Selabintana. Hal ini menunjukan bahwa gaya kepemimpinan dan kesejahteraan sangat berperan penting dalam peningkatan kinerja karyawan. Maka dari itu, Hotel Selabintana perlu adanya evaluasi mengenai gaya kepemimpinan yang tepat dalam memimpin dan diharapakan dalam pembagian insentif dan kompensasi yang tepat waktu sehingga karyawan merasa sejahtera demi terciptanya kinerja karyawan yang produktif.

b. Saran Untuk Peneliti Lain

Dengan adanya hasil penelitian ini diharapkan peneliti lain dapat melakukan penelitian baru yang lebih dikembangkan dan menemukan faktor-faktor lain yang tidak diteliti pada penelitian ini.

\section{Daftar Pustaka}

Arikunto, S. (2013). Prosedur Penelitian Suatu Pendekatan Praktik. Rineka Cipta.

Gzohali, I. (2013). Aplikasi Analisis Mutivariate dengan Program IBM SPSS 21 Update PLS Regresi. Badan Penerbit Universitas Diponegoro.

Komariyah, E. E. Y. A. I. (2017). Manajemen Sumber Daya Manusia Strategi dan Perubahan dalam Rangka Meningkatkan Kinerja Pegawai dan Organisasi. Alfabeta.

Sudaryono. (2017). Pengantar Manajemen Teori dan Kasus. CAPS (Center for Academic Publishing service).

Sugiyono. (2015). Metode Penelitian Kuantitatif, Kualitatif dan $R \& D$. Alfabeta.

Undang- Undang No 13 Tahun 2003. (n.d.).

Undang-Undang Nomor 8 Tahun 1997. (n.d.).

Yati Suhartini; Tri Septiningsih. (2014). Pengaruh Kesejahteraan Karyawan Terhadap Motivasi Kerja Karyawan pada RSU Rachma Husada Bantul Yogyakarta. Jurnal Akuntansi Dan Manajemen, Vol 11 No. 